\title{
铛
}

DAVID C. WEBER

\section{A Century of Cooperative Programs Among Academic Libraries}

A among colleges and universities over the last century leads to the conclusion that a few very significant developments and changes have taken place during the past decade after ninety years of laborious and diverse effort toward cooperative programs dominated by the effects of national policy and economic conditions. It is an interesting history, one made difficult by the plethora of data. The present paper uses a historical perspective in order to assess better the present and the immediate future. The first part chronologically presents selected examples of cooperative programs. The latter section includes details on a few programs of current special significance, comments on some strengths and weaknesses, and reaches a few conclusions.

\section{Early Historical Review}

Before reviewing the past century, it may be worthwhile taking a brief look at circumstances in academic libraries two hundred years ago. At that time academic libraries in America were indeed insignificant by today's perspective. Dartmouth had 305 volumes. Brown University owned 312 volumes including fifty-two received in 1772 which were "by far the greatest donation our little library has yet had." Princeton had more than 1,200 volumes, all to be con- sumed by fire in 1801 . The University of Pennsylvania's chief distinction in 1776 was that during the Revolution it had received a gift of scientific books from Louis XVI. Columbia stored its volumes during the war in the city hall or elsewhere; British soldiers took them to barter for grog, and only six or seven hundred volumes were found-thirty years later-in St. Paul's Chapel. By the time of the Revolution, Yale had collected over 4,000 volumes in its library. The College of William and Mary had a very few thousand volumes. Harvard had lost all but 404 volumes of its library by fire in 1764 , yet by the Revolutionary War it had been rebuilt probably to nearly 10,000 volumes.

By 1876 the circumstances were markedly different. Great libraries had come upon the American scene. Some remarkable librarians had created most of the essential concepts and policies for library administrative methods. Collections began to grow rapidly, with a great deal of attention necessarily given to cataloging and classification. The year 1876 was momentous in that the American Library Association was formed. ${ }^{1}$ The American Library Journal was founded with four of its twenty-one associate editors "leading the profession" from university libraries. The Library Bureau was established as a supply house providing a major force toward 
standardization. It also was the year in which the classic volume, Public $\mathrm{Li}$ braries in the United States of America; Their History, Condition and Management, was published by the United States Bureau of Education. One looks in vain, however, in that major volume of 1,187 pages for any statement regarding cooperation among academic libraries.

Cooperative cataloging was one of the very first interests of the new library association. A committee was formed to devise a plan for continuation of Poole's "Index to Periodical Literature," and another committee tackled the matter of standardization of cataloging. Several articles in the Library Journal discussed plans for cooperation in indexing and cataloging. Yet it was a Committee on Cooperation in Indexing and Cataloguing College Libraries, which was appointed August 1876, that is significant with respect to academic cooperation. It was formed by the librarians of the University of Rochester, Cornell University, Vassar College, Syracuse University, and the New York State Library. This committee presented to the University Convocation of the State of New York in July 1877 a substantial report which called upon college libraries to speak out on any special adaptation of the cooperative cataloging movement which was required for their special wants:

At present the work is chiefly in the hands of the public libraries. ... In making this report your committee do not wish to be understood as endorsing fully all the methods proposed by the committees of the Library Association. It is very doubtful whether as good cataloging can be done, in the manner proposed, by a considerable number of libraries, even under very explicit rules, as might be expected of one or two experts, who should work for pay under the general direction and criticism of the committee. Cooperation can be secured quite as effectively by a combination of capital as by a combination of labor. In such an enterprise the first most important thing to be aimed at is perfection of work. . . . Other points might be mentioned but a review of the methods proposed is not the object of this report. We believe that it will be far better for us to work with the Library Association, though we may differ in opinion as to some details, than to undertake any separate work in this state. ${ }^{2}$

The decade of the 1890 s witnessed the beginnings of major national programs of academic library cooperation. It did not come unannounced onto the scene. There had indeed been discussions over several previous decades, at least since 1851 , and no doubt there may have been a large number of local arrangements of such cooperation. In 1898 the librarian of the University of California announced willingness to lend to other libraries that would lend to the University of California.

In January 1898 the American Library Association began publishing analytic cards as a shared indexing/cataloging program. The copy for these cards was prepared by five major libraries for articles in some 250 serials. The H. W. Wilson Company took over this analytic activity in June 1919 for incorporation into the International Index of Periodicals.

\section{Into The Twentieth Century}

In another consideration, the librarian of Princeton University, Ernest C. Richardson, proposed in the spring of 1899 "a lending library for libraries" and suggested that this might be the Library of Congress or an independent organization.

The Library of Congress issued a policy governing interlibrary loans in 1907 and lent to such an extent that by 1909 it loaned 1,023 volumes to 119 libraries -including forty-nine academic libraries which accounted for half of these loans. An ALA interlibrary loan 
code was first published in 1916.

If a union catalog of holdings is permitted within the definition of cooperation, there were then major developments, notably so in the first decade of this century. The first regional union catalog was created in 1901 at the California State Library. After first being limited to periodicals, it was soon enlarged to cover all nonfiction. The National Union Catalog was established in 1900. In November 1901 the Library of Congress began selling copies of its printed catalog cards as well as galley proofs of these cards. During the winter of 1901-02 it began the donation of complete "depository" sets of cards to certain libraries. Some libraries receiving these began immediately to file them into their public card catalogs, thus constituting union catalogs. The University of Chicago Library from 1913 and the Harvard College Library from 1911 published printed cards, the scope designed to supplement LC and complement each other. Chicago distributed its cards from 1913 until 1917. (When Chicago began distributing its cards May 2, 1913, those titles also owned by Harvard, about 30 percent, appeared with the symbol "UCL-HCL.") The University of California issued them from 1915 to 1917. In July 1918 the University of Chicago began publishing analytic cards for certain European serials. The University of Michigan published for some time after 1924; the University of Illinois started in 1926. Wesleyan University published cards sold to thirtytwo research libraries from 1934 until World War II. The Library of Congress established its Cooperative Cataloging Division in $1932 .{ }^{3}$

Another cooperative endeavor is that of joint acquisition programs. Perhaps the earliest example is the 1913-14 South American buying trip to eleven countries by Walter Lichtenstein, the Librarian of Northwestern University. $\mathrm{He}$ acquired 9,000 volumes plus news- papers and a few manuscripts on behalf of Harvard University, Brown University, Northwestern University, the John Crerar Library, and the American Antiquarian Society. One or two features of this joint effort are of note:

In Venezuela and Bolivia and partly also in Brazil the purchases consisted of collections which had to be divided among the cooperating institutions, and naturally included a fair amount of material which, either because the cooperating institutions already had it or because the class of material in question is not collected by the institutions which I represented, can be sold to other libraries in this country. The purchase of collections on joint account in this manner was a new experiment. It did not seem to me to be wholly satisfactory. The chief difficulty was that the material could not be readily divided until my own return to this country, with the result that no one knew until I did return how much each institution was liable, and hence I was considerably hampered in making further purchases. As it finally turned out, one institution acted to a large extent as banker for the other institutions, which evidently is pleasant enough for the latter, but is not quite fair to that institution which has the misfortune to be the banker.... When the collections came to be divided it was soon felt that the only possible way to divide the cost among the institutions interested was to devise a system of points. A pamphlet was counted as one point, an unbound volume as four, and a bound volume as eight. ${ }^{4}$

It seems quite certain that the increase in publishing in the $1850 \mathrm{~s}$ and the economics surrounding the Civil War brought an end to the common practice of publishing library catalogs periodically in book form. It also thereby hastened the adoption of unitary catalog cards which during the last quarter of the nineteenth century became the prevalent mode for listing 
holdings and facilitated sharing of bibliographic data. If the more affluent times of the $1880 \mathrm{~s}$ and $1890 \mathrm{~s}$ resulted in phenomenal growth of collections, it may have been predictable there would be an upsurge in cooperative proposals and the beginning of national cooperative programs.

Despite the 1927 publication of the great Union List of Serials in Libraries of the United States and Canada, it would seem that the decade of the 1920s was not a period of new concepts in academic library cooperation. With the crash of 1929 and conditions of the Great Depression, however, there was impetus for cooperation which led to new programs of which a few among academic libraries may be cited.

Dozens of new union card catalogs were begun in the 1930s, stimulated by the vast federal relief program. One result was the 1940-41 survey under the sponsorship of the ALA Board of Resources of American Libraries which recommended their future coordination to assure thorough coverage, minimum overlap, and sound fiscal support.

As a predecessor to cataloging-in-publication and the National Program for Acquisitions and Cataloging (NPAC), the Cooperative Cataloging Program began in 1932. Within ten years nearly 400 U.S. and Canadian libraries contributed data for 60,000 scholarly titles for LC editing and publication.

An informal arrangement among several institutions constituted the Cooperating Libraries of Upper New York, CLUNY. Formed in 1931, it included Buffalo University, Colgate University, the Grosvenor Library, Hamilton College, Syracuse University, Cornell University, and Union College. This group functioned until 1939 as a clearinghouse for mutual problems and cooperated on a union list of periodicals and the joint purchase of microfilm of early English publications.

An example of a formal agreement is the Duke University and the University of North Carolina interlibrary project. In 1931 these two institutions agreed to special book collecting areas, and the libraries exchanged author cards for their catalogs. Four years later a messenger service commenced. Two other North Carolina institutions joined in 1955, and full borrowing privileges were extended to all members of each institution.

An example of contractual arrangements among several libraries is the Joint University Libraries founded in 1936 by Vanderbilt University, George Peabody College, and Scarritt College for Christian Workers. Operating under a joint board of trustees, the facility is an independent entity, jointly owned and financed by the participants. ${ }^{5}$ Another example is The Claremont Colleges library system which began in 1931 when a contractual arrangement among the Claremont Graduate School, Pomona College, and Scripps College established a joint order and catalog department to serve the three libraries.

A 1933 example of an arrangement for reciprocal borrowing privileges is the Atlanta University Center Corporation in Atlanta, Georgia. With an initiating grant from the General Education Board it included Atlanta University, Morehouse College, Spelman College, Morris Brown College, Clark University, and in 1957 the Interdenominational Theological Center.

Another variation of interinstitutional cooperation is the unification of academic libraries under state control. This was pioneered in 1932 by the Oregon State Board of Higher Education which appointed one director of libraries for the entire state system and established the principle of free circulation among all state institutions. It also set up a central order division which now takes the form of a combined author list of all books and periodicals in the state 
system maintained in the Order Department of the Oregon State University Library "to eliminate unnecessary duplication of materials." 6

\section{More Recent Events}

A highly selective list of other cooperative programs of the past forty years would include the following:

1942-Opening of the New England Deposit Library (NEDL) as a cooperative storage facility of Boston College, Boston University, Harvard University, M.I.T., Radcliffe College, Simmons College, Tufts University, and four nonacademic libraries.

1944-The Cooperative Committee on Library Building Plans initiated by President Dodds of Princeton to concern itself with common problems in the planning for and design of academic library buildings.

1946-The Cooperative Acquisitions Project for Wartime Publications conducted by the Library of Congress which, over three years, shipped nearly a million volumes from Europe to 113 participating American libraries.

1948-Formation of the Universal Serial and Book Exchange, Inc. (previously named the U.S. Book Exchange). Of the initial members, 106 (76 percent) were college or university libraries; they continue to deposit about 70 percent of the material exchanged, and they receive about the same percentage of the total distributed.

1948-Start of service under the Farmington Plan to about sixty research libraries of a coordinated foreign acquisition program for current materials of research value-a cooperative program born of disconcerting experiences with European acquisitions during and immediately following World War II. This major cooperative program was one of the most effective and significant over many years. With 1965 as an example, fifty-two libraries acquired 22,419 volumes, constituting the total research publications from fourteen countries, in addition to area assignment receipts from the lessdeveloped countries.

1951-Opening of the Midwest InterLibrary Center, later to be known as the Center for Research Libraries, by ten midwestern university libraries as a cooperative akin to the NEDL but with a program for joint buying and different categories of deposit or center ownership.

1956-Initiation of the Foreign Newspaper Microfilm Project as a cooperatively filmed, sharedpositive-copy program managed by the Association of Research Libraries, the offspring of Harvard's duplicate sale program begun in 1938 .

1959-The Latin American Cooperative Acquisitions Program (LACAP), begun as a commercial endeavor for about forty academic libraries. ${ }^{7}$

1961-Congress authorized expenditures under Public Law 480 of blocked currencies for acquisition and cataloging of multiple copies of publications from eight countries. Managed by the Library of Congress, this PL 480 program benefited over 300 academic libraries, with materials from Ceylon, India, Indonesia, Israel, Nepal, Pakistan, United Arab Repub- 
lic, and Yugoslavia.

1965-The Medical Library Assistance Act, creating, among other programs, the eleven Regional Medical Libraries providing interlibrary loan and reference and consultation services to a broad region. Seven are located in universities: Harvard, University of Washington, Wayne State, UCLA, Emory, Texas, and Nebraska.

1966-The National Program for Acquisitions and Cataloging (NPAC), managed by the Library of Congress and initiated by the Association of Research Libraries.

1966-The New York State Reference and Research Library Resources Program (3Rs Program) established to facilitate use of research library materials.

1967-Incorporation of the Ohio College Library Center (OCLC) as a cooperative cataloging service for Ohio colleges and universities.

1968-The Center for Chinese Research Materials, formed by the Association of Research Libraries for acquiring, reprinting, and distributing selected valuable but inaccessible Chinese scholarly materials.

1973-The Research Libraries Group, formed of Harvard University, Yale University, Columbia University, and the New York Public Library, to undertake a program of coordinated collection building, reciprocal access privileges, delivery service, and a common computer storage of catalog records for their collections so as to enhance coordinated acquisitions and resource sharing.

The composition of programs for four cooperatives begun in the late 1960 s may be cited as typical. The Five Associated University Libraries (FAUL) in New York (Buffalo, Rochester, Syracuse, Cornell, and Binghamton) currently includes assigned subject specialization for acquisitions, delivery service, photocopying, reciprocal borrowing, expanded interlibrary loan service, and joint research projects. The Librarians of the Council of Independent Kentucky Colleges and Universities encompasses twenty-one colleges active in joint purchase, assigned subject specialization, reciprocal borrowing privileges, expanded interlibrary loan service, and production of union lists and directories. The Middle Atlantic Research Libraries Information Network (MARLIN) of seven universities includes delivery services, photocopying, mutual notification of purchase, production of union lists and directories, expanded interlibrary loan, and special communication services. The North Dakota Network for Knowledge of seventeen college and university libraries plus thirteen public and special libraries includes all of MARLIN's program except purchase notification and also provides mutual reference services, reciprocal borrowing, and operation of a special bibliographic center.

One or two cooperative liaisons were formed every year or so from 1930 until 1960 when there was a sharp increase. The Delanoy-Cuadra directory lists the births: four in 1964; seven in 1965; eleven in 1966; sixteen in 1967; twentyfour in 1968; twenty-four in 1969; and at least nineteen in $1970 . .^{8}$ If one had a comparable mortality list, one might speculate that some of these would falter. Yet a spot check found none of those listed as formed during the 1960s were deceased by 1975 .

\section{Short-Lrved EFforts ALso Provide Lessons}

Yet it must also be recorded that some 
major attempts at cooperation among academic libraries petered out or failed, though much may have been learned. An evaluative history of library cooperation is faced with problems. Joe W. Kraus has written:

Several difficulties present themselves
at the outset. The literature of library
cooperation is very large and most of
the articles are uncritical. Although
most of the cooperative enterprises of
libraries are announced and described
in some detail in library periodicals,
there are few evaluative reports that
give a clear account of the success of
a venture and the factors leading to
success or failure. Unsuccessful ones,
in fact, simply seem to fade away.
Costs of a cooperative effort are par-
ticularly hard to ascertain, in part be-
cause many expenses are absorbed in
the participating libraries, and in part
because standard reporting procedures
have generally not yet been devel-
oped. ${ }^{9}$

One may here cite the Columbia-Harvard-Yale medical library computerbased cooperative cataloging program that was terminated after operating from 1963 to 1966 . As stated in the research proposal issued in December 1962 from the Yale Medical Library, the objective of the project was to test the feasibility of using a computerized catalog to provide rapid and improved information services in medical libraries. An on-line system was projected; the significant achievements were the recording of 23,000 titles and the automated production of catalog cards. (It was the precursor of OCLC.) An array of technical problems concerned input procedures. A change in data format standards was needed. Authority files were lacking. The subject treatment caused great problems, as did error-detection procedures. There were problems of staff cooperation and communication. $^{10}$ Operational methods among the three participants varied widely, and detailed documentation of procedures and decisions was lacking. Furthermore, "it had become apparent that a latent conflict of purpose had begun to form between the interests of the inter-institutional Project comprising divisional, i.e., medical libraries, and the interests of the individual university library systems where the medical library is but one of the integral units."11

Another which did not last long was the Colorado Academic Libraries Book Processing Center, which also operated for only three years. This Colorado project began in 1965 with nine academic libraries. The test phase, operated for fourteen institutions, lasted from early 1969 until 1973 and covered the full range of acquisitions, cataloging, processing, and bookkeeping. Its problems were incompatibilities among library procedures; changes not made by all of the individual libraries; differences in size, traditions, and service philosophies; and failure to recognize that errors were inevitable. Turnaround time was below expectation and generally inferior to that obtained when libraries ordered direct from publishers or jobbers. Communication breakdowns accounted for many problems. Geographical separation of participants was partially to blame, and staff did not understand the center's role or how it would affect their jobs, future, and status. Furthermore, "centralization, cooperation, and computerization have created a library environment that is completely alien to many librarians." 12 Its final processes were phased out in 1973.

The most successful acquisition and processing centers, both founded in 1969, are the Cooperative College Library Center, Inc., in Atlanta, and the Massachusetts Central Library Processing Service in Amherst. From the latter, thirty-one institutions were provided acquisition support and cataloging; a million items have been processed by its batch computer process. Exceedingly low costs were achieved under con- 
straints which constitute mass production methods. The program was successful in bringing public higher education librarians together in an organized way, which was timely since the Commonwealth Legislature eliminated funding for fiscal year 1976 .

More often those cooperatives that were weak were merged into other programs, reduced to a smaller practical element, or superseded by a newer, larger, and more effective program. An example of a program which served its time is the Farmington Plan of 1948 to 1972 which was obviated as strength was gained by the National Program for Acquisitions and Cataloging (Title II-C of the Higher Education Act signed into law November 8,1965$)$. The PL 480 program was also a factor. ${ }^{13}$

\section{Diversity in Recent EfForts}

Academic library cooperation is clearly flourishing. After many experimental starts, there seem to have been persistent efforts since the 1930s. Such programs continued to grow in number and magnitude after World War II. It may indeed be asserted that the efforts since World War II have become more formal, more extensive, and far more expensive than previous efforts. Developments such as the New England Deposit Library and, particularly, the Center for Research Libraries demanded active participation and support by college presidents. A program such as the National Program for Acquisitions and Cataloging involved Congressional lobbying with resultant major appropriations and sweeping impact. The formation of the Ohio College Library Center demonstrated that cataloging operations could be effectively supported daily through on-line access to a single computer system. Formation of the Research Libraries Group indicated that not only the libraries of OCLC but also the largest academic and research libraries in the nation found the need and the means for a major effort involving a legal instrument, highly expert professional staff, fund-raising programs, and locally contributed effort.

The more prevalent existing programs found among 125 consortia (of which 60 percent were incorporated) may be tabulated as follows: ${ }^{14}$

reciprocal borrowing privileges -97 expanded interlibrary loan service $-80$

union catalogs or lists -78

photocopying services -72

reference services -50

delivery service-44

mutual notification of purchase40

special communications service- -35

publications programs -34

catalog card production-34

other cataloging support-33

joint purchasing of materials -30

assigned subject specialization of acquisitions -28

Quite clearly there are few completely innovative programs. An effort like the Research Libraries Group contains elements from a number of programs of the past forty-five years. In his recent article, "An Historical Look at Resource Sharing," Basil Stuart-Stubbs concluded:

If the word network wasn't prominent in the vocabulary of our pioneers, the concept was there. In fact, although the centennial of Samuel Swett Green's proposal for interlibrary lending will be celebrated next year [i.e., 1976], and although the dimensions of cooperation among libraries have increased enormously, there have been few intellectual innovations in the interim years. Wherever the spirits of our predecessors now abide, they must be waiting for the realization of their ancient hopes. ${ }^{15}$

Just as there are few completely novel twists to academic library cooperation, so also one can find little novelty in the impetus for and obstacles to cooperative programs. Joseph Becker has cited the 
motivating factors of service, economics, and technology. ${ }^{16}$ John P. McDonald expanded these to include financial constriction, cost sharing, availability of funds, pressure of numbers, resource improvement, service improvement, management improvement, image enhancement, and technological development. To these nine forces urging cooperative enterprise, he has also cited a number of obstacles.

If there are incentives to cooperation, there are also many problems and difficulties that limit or frustrate our best efforts at collective action. There is, for example, a persistent attitude that assigns cooperative activities low priority and low or no budget. This viewpoint insists that cooperation be undertaken as a part-time extra duty and then only after more important work has been accomplished. There are other attitudes that have proved difficult to overcome. It is asserted that cooperation causes delay and inconvenience resulting in a general deterioration in service. Other complaints are that cooperation is expensive, that it involves high effort for low return, that there are inequities in contributions and benefits, and that cooperation is often ill defined or redundant. ${ }^{17}$

These problems may be endemic with any cooperative program-less visible where cooperation between two departments of a single library is concerned but exposed to view and psychologically much more difficult to resolve when cooperation between two institutions is undertaken. When one remembers that almost any two institutions are disparate in program, financial support, and a host of other variables, one may wonder whether any cooperation can be effective and lasting. ${ }^{18}$

The challenges, the opportunities, and the problems do not seem to change fundamentally with the passing of time. This may be true even for technological development. In 1851, three years after Charles C. Jewett left Brown University to become Librarian of the newly established Smithsonian Institution, he proposed the stereotype printing of cataloging data. ${ }^{19}$ However, the spirit of cooperation was blunted by the difficulties of organizing the business and the unexpected warping of the plates. The Library of Congress card distribution plan of fifty years later pursued this same promise of a new technology which could solve problems of individual libraries.

\section{Historical Lessons}

The relative impact of these obstacles will change with respect to each cooperative endeavor. Furthermore, each endeavor is commonly a mix of several incentive factors and must cope with a variety of obstacles..$^{20}$ What can be concluded from this review of cooperative programs over the last century?

In 1945 an assessment was made by Robert B. Downs. His study revealed

certain important principles which have influenced the success or failure of various kinds of library cooperation. First, distance is a handicap, and it is easier for libraries not too far removed from each other to work together. Second, regional library cooperation has its greatest opportunities in those areas with inadequate book resources. Third, libraries should not be asked to give up anything but rather to assume positive responsibilities and receive direct benefits. Fourth, agreements must be flexible enough to provide for expansion and adjustment. Fifth, complete elimination of duplication between libraries is not possible or desirable. Finally, only a comparatively limited number of libraries are at present equipped to make any substantial or effective contribution to a general program of cooperation on the research level. ${ }^{21}$

A university president provided another assessment. 
It is my personal judgment that those that work best are of two sorts: they are either between universities, or parts of universities, of equal status and quality or, at the other extreme, between universities, or parts of universities, that differ widely in status or quality. .... But where the gradations in quality are small in extent but noticeable, co-operation is exceedingly difficult. . . . the obstacles to co-operation are not material. ... . [They] are found in the mind and spirit of man. They are institutional pride and institutional jealousy. ... . They are inertia and complacency. It is self-satisfaction, institutionwise, that makes the building of effective co-operation a difficult thing. And I would say, final$l y$, that it is an irrational provincialism or an emotional particularism on the part of college faculties which makes co-operation difficult. ${ }^{22}$

To some extent there are cycles of popularity. Within a decade after the New England Deposit Library was opened, the Center for Research Libraries and the Hampshire Inter-Library Center came along, soon followed by local storage facilities for Princeton University, the University of Michigan, and the University of California at Berkeley. At the moment, computer-related programs are clearly looked upon as holding great promise. They are the prime, but not the only, objective of consortia such as NELINET founded in 1966, SOLINET (1974), MIDLNET (1974), and CLASS (1976). For instance, MIDLNET, the Midwest Region Library Network, includes research libraries and state networks in Michigan, Indiana, Wisconsin, Minnesota, Illinois, Iowa, and Missouri; it aims to develop faster delivery of books to users; to coordinate library planning, development, and research in the Midwest; to attract federal funds available for regional library network development; to provide a voice in the emerging national library network; and to develop a coordinated program of materials preservation. Each of these programs rides some wave pattern of popularity and success. Each individual library tries its ability to swim in the current, but none operates apart from circumstances in its own institution. Library changes can be found to be closely derivative of their institutional conditions and/or national circumstances. ${ }^{23}$

The cause and effect can sometimes be clearly traced. For example, projects supported by the Library Services and Construction Act Title III (signed into law July 1966) for intertype cooperatives obviously show derivation from that federal law. One can cite the 1972 Cooperative Information Network in California which was formed of 250 libraries, including the University of California campus at Santa Cruz, the Universities of Santa Clara, San Jose State, Golden Gate, and Stanford together with over a dozen community colleges and the U.S. Naval Postgraduate School. Yet the New England Deposit Library was born of space problems mounting during the depression years, although the concept was proposed by Harvard's President Eliot. In the fall of 1901, Eliot wrote that

the increasing rate at which large collections of books grow suggests strongly that some new policy is needed concerning the storage of these immense masses of printed matter. . . . It may be doubted whether it be wise for a university to undertake to store books by the million, when only a small proportion of the material stored can be in active use. Now that travel and sending of books to all parts of the country has become cheap, it may well be that great accumulations of printed matter will be held accessible at only three or four points in the country. ... The unused might be stored in a much more compact manner than they are now, even in the best-arranged stacks. ${ }^{24}$

The concept is venerable, but it had to await implementation until the massive 
Widener Library was full in the 1930s. Then the New England Deposit Library was justified and financed.

Timing is often key, as with the NEDL. The Center for Research Libraries was initiated under the name Midwest Inter-Library Center. But ten years before its foundation President Robert M. Hutchins of the University of Chicago asked Keyes D. Metcalf to conduct a study of such a cooperative facility for twelve Midwest universities stretching from Ohio to Minnesota and Michigan to Missouri. Eleven of the twelve university presidents approved the idea, and only one was opposed. However, eleven of the twelve librarians opposed the idea, and only one approved of it. Metcalf suggested the matter be put off until after the approaching war. When a new study was then made, it turned out that all but one of the librarians had changed and all but one of the presidents had retired. Eleven out of twelve current incumbents of both groups then approved. Thus can ten years change attitudes toward interlibrary cooperation.

Recent cooperative examples face most if not all of the problems treated above, develop under similar motivations, and seem to follow principles influencing their success which are the same as similar programs of past decades. One significant difference seems to be the greater legal and administrative formality required. In this connection, it may be useful to review the purposes for creation of the Center for Research Libraries, the Ohio College Library Center, and the Research Libraries Group. These may be typical of the next significant wave of developments.

\section{EXAMPLES OF INCREASED FORMALITY}

The Center for Research Libraries was incorporated in 1949 by ten universities as a nonprofit corporation with the primary purpose of increasing the library research resources available to co- operating institutions in the Midwest. Four areas of activity were initially outlined:

The deposit into a common pool of the infrequently used library materials held by the participating institutions in order to reduce their local space needs, and also to make more readily available when needed more complete collections than any one of the participating libraries itself could reasonably maintain for its own exclusive use.

The cooperative purchase and centralized cataloguing and housing of infrequently used library research materials that were not already adequately available to the participants.

The centralized acquisition and cataloging [sic] of the materials acquired by the participants for their own collections.

The coordination of the acquisitions of the individual participating libraries to avoid unnecessary duplication. ${ }^{25}$

A building for the center was occupied in 1951. Within a dozen years the cooperative acquisition program had been given increased emphasis. The most significant shift came in 1963 when the center invited Stephen A. McCarthy and Raynard C. Swank to survey the program and make recommendations dealing with concerns such as the gradual assumption of many characteristics of a national interlibrary center while its base of support was primarily regional; questions of whether the center's activities were truly worth their cost to the members; how it could be of better service to all of the nation's research libraries (and potentially of Canada and Mexico as well); and how it might most effectively broaden its base of support. The most significant recommendation was that:

The Center should formally cease to be a regional agency and should become a national institution. 
All suitable methods of bringing about this change should be fully explored.

In seeking the best means of becoming a national research library center, the possibility of a relationship with the Association of Research Libraries and contractual relationships with the Library of Congress and other federal agencies should be thoroughly investigated. ${ }^{26}$

Among many recommendations and changes in the acquisition program, this change to a national scope and alterations of its governance, funding, and operations have been especially significant, and have led to an increase in its membership from the original ten universities to a present total of sixty.

The Ohio College Library Center was incorporated in 1967 by nine public and private colleges and universities as a notfor-profit corporation. There were fiftyfour members during 1967-68. The OCLC Articles include the statement that:

The purpose or purposes for which this corporation is formed are to establish, maintain and operate a computerized, regional library center to serve the academic libraries of Ohio (both state and private) and designed so as to become a part of any national electronic network for bibliographical communication; to develop, maintain and operate a shared cataloging program based upon a central computer store; to create, maintain and operate a computerized central catalog (inventory) of books and journals in the participating libraries; and to do such research and development related to the above as are necessary to accomplish and to extend the concept. ${ }^{27}$

That same year the OCLC trustees approved a general statement of two principal goals for the organization:

These goals are, 1) increase of resources for education and research to faculty and students of its member institutions, and 2) the deceleration of per-student costs in its member colleges and universities. Techniques for achieving these goals include library and the new library-like information servicing techniques, such as dial-up installations, audiovisual centers, and computer assisted instruction. Although "academic libraries" of the immediate future must be looked upon as including all of these activities, only the traditional library is presently common to all institutions which are OCLC members. Therefore, major emphasis in planning and development will continue to be for activities associated with classical library operations. However, OCLC will stand ready to participate in newer information servicing activities, and it may well be that furnishing powerful computation service will be among its earliest activities. ${ }^{28}$

In 1974-75, participating libraries cataloged 2,555,055 books; the data base contained over 5.3 million locations. Cataloging using existing records in the on-line catalog increased to 84.7 percent. Use of records for catalog production by libraries other than the one inputting the record rose to 41.8 percent. This indicates a major operational interlibrary endeavor.

The Research Libraries Group was formed by Columbia, Harvard, and Yale Universities and the New York Public Library to develop a common bibliographic system, cooperative acquisitions, shared resources, and a program of book conservation. The presidents of the three universities gave their strong endorsement to the RLG concept, and the Trustees of NYPL demonstrated their support by voting in October 1974 to allow materials from the research libraries to be sent to other RLG members on interlibrary loan. The Research Libraries Group is governed by a board of directors with working committees on policies and programs for preservation, collection development, serials, readers services, bibliographic pro- 
cesses and control, and systems and technology applications. It has created a joint bibliographic center and appointed a president and vice-president for systems. It was incorporated in December 1975 as a not-for-profit corporation. The certificate of incorporation presently includes the statement:

The nature of the activities to be conducted, or the purposes to be carried out by the corporation, are as follows: (a) to promote coordination in the development of library collections, and to develop cooperative programs in the conservation and preservation of library materials; (b) to develop improved methods for identifying and locating recorded information in libraries and for creating and using bibliographic systems; (c) to develop, operate, support and coordinate cooperative programs to improve physical access to the collections of libraries; (d) to improve the efficiency and to promote economics in the operations of libraries; (e) generally, in any and all lawful ways to improve library services provided by the Members; and (f) to engage in any other lawful act or activities (consistent with the foregoing purposes). ${ }^{29}$

In its first report to a supporting foundation, the RLG restated that rapid development of a limited number of cost-effective programs is viewed as the basis for eventual solicitation of other members similar in nature to the founders and possibly selling services on a cost-recovery basis to other libraries.

\section{ASSESSMENTS OF USEFULNESS}

How useful are existing cooperative programs from the point of view of the college or university student or professor? One finds little data that can help in the evaluation. It may be worth noting that there have been almost no published research studies comparing and analyzing two or more cooperative programs of a similar nature. ${ }^{30}$

A tabulation of cataloging copy con- tributed to the National Union Catalog indicates records which constitute interlibrary loan potential for other institutions as well as potential shared cataloging. In 1974-75, academic libraries contributing the largest number of cards were the following:

$\begin{array}{lr}\text { University of Texas } & 124,209 \\ \text { Harvard University } & 113,830 \\ \text { University of Wisconsin } & 105,386 \\ \text { Cornell University } & 97,494 \\ \text { University of California, } & \\ \text { Berkeley } & 83,213 \\ \text { Yale University } & 78,230 \\ \text { Rutgers University } & 76,277 \\ \text { Princeton University } & 74,353 \\ \text { Columbia University } & 68,751 \\ \text { Duke University } & 67,795 \\ \text { Indiana University } & 66,548 \\ \text { Ohio State University } & 66,060\end{array}$

Since universities use LC cataloging for from 35 percent to 89 percent of their material, the value of help via NUC, MARC, NPAC, and other LC Processing Department products is clearly in the tens of millions of dollars.

Statistics of interlibrary lending and borrowing are evidence of the value of one universal cooperative program. Using a sample of academic libraries, the picture for 1974-75 is shown in Table 1.

Of all recorded circulation, the interlibrary traffic constitutes an almost infinitesimal proportion-an aggregate average of 1.79 percent for colleges and 1.33 percent for universities! It is the most expensive form of resource sharing. (It may cost 5 cents to circulate a reserve book, 10 cents from the general stack collections, $\$ 1.00$ from a locked stack, $\$ 2.00$ from a campus auxiliary stack, but it costs from $\$ 4.00$ to $\$ 9.00$ by interlibrary loan.)

Specific evidence is available of another type of program directly benefiting patrons-commuting service for persons to another library. An instance is the intercampus bus service estab- 
TABLE I

INTERLIBRARY LENDING AND BORROWING AND TOTAL RECORDED Circulation, Selected Colleges and Universities, 1974-75

\begin{tabular}{lrrr}
\hline \hline $\begin{array}{l}\text { Name of } \\
\text { Institution }\end{array}$ & $\begin{array}{c}\text { Items } \\
\text { Borrowed }\end{array}$ & $\begin{array}{r}\text { Items } \\
\text { Lent }\end{array}$ & $\begin{array}{c}\text { Total Recorded } \\
\text { Circulation }\end{array}$ \\
\hline Colleges & & & \\
Amherst & 1,826 & 2,424 & 62,092 \\
Bowdoin & 287 & 1,504 & 84,212 \\
Colby & 863 & 387 & 80,993 \\
Denison & 143 & 94 & 46,816 \\
Goucher & 23 & 17 & 44,262 \\
Ithaca & 559 & 600 & 105,421 \\
Middlebury & 1,430 & 1,206 & 89,358 \\
Mills & 22 & 45 & 41,906 \\
Oberlin & 1,408 & 2,751 & 290,386 \\
Occidental & 36 & 21 & 85,040 \\
Reed & 199 & 316 & 38,906 \\
Stephens & 16 & 5 & 61,264 \\
Vassar & 2,823 & 3,218 & 104,832 \\
Weber State & 379 & 50 & 87,840 \\
Westmount & 159 & 103 & 37,247 \\
Wooster & 459 & 98 & 48,739 \\
Universities & & & \\
Delaware & 3,301 & 2,953 & 394,022 \\
Humboldt State & 1,008 & 412 & 437,819 \\
Illinois & 4,427 & 43,729 & $1,882,960$ \\
Kansas & 6,126 & 7,346 & $1,033,353$ \\
Long Beach, Cal. State & 3,311 & 1,402 & 944,577 \\
Michigan & 5,910 & 8,939 & $1,565,148$ \\
Northwestern & 1,311 & 3,653 & $1,014,701$ \\
Pennsylvania & 2,612 & 9,079 & 545,293 \\
Stanford & 3,529 & 16,737 & $1,481,675$ \\
Texas & 2,648 & 1,615 & $1,626,449$ \\
UCLA & 4,006 & 5,695 & 549,468 \\
Utah & 4,549 & 6,848 & 521,742 \\
Virginia & 1,962 & 53,055 & $2,792,968$ \\
U. of Washington & 3,349 & & \\
\hline & & 549 & \\
\hline & & & \\
\hline
\end{tabular}

lished in late 1961 by the University of California. Transporting scholars and books six days each week, it operates from Davis and Santa Cruz to Berkeley, and from Irvine, Riverside, San Diego, and Santa Barbara to UCLA. During 1972-73 there were over 16,000 passengers plus 35,000 complete interlibrary or returned personal loans. A study in early 1974 revealed half of the commuters used library services or collections; the others used laboratories, attended classes, or were otherwise on university business. Before making the trip, 19 percent had conferred with a local librarian about the resources to be visited, and 58 percent went with some preknowledge of what they would find. A third of the commuters checked out a book, the return of which by a later bus constituted a third of the above annual quantity of loans while the other twothirds were interlibrary loans including the 9 percent personally fetched and charged out by the bus driver. Here is another quantifiable example of practical interinstitutional sharing of library resources.

One looks in vain in published library literature to find major comprehensive cost-effectiveness studies of joint acquisitions programs or interlibrary borrowing. To the patron they are relatively marginal programs when viewed against the totality of library services in any one college or university. Institutions have obviously recognized that the final 1 percent of service volume 
justifies costs that are disproportionate.

\section{The Nature of Future Prospects}

It is difficult to discern trends. Interinstitutional cooperation seems to be universally recognized as essential, although the extraordinary efforts required and the hazards in the course are now understood-and continue to exist. In some sense a library is only effective if it has acquisition, processing, and service programs; physical facilities in which to house the collections and readers; and a specialized staff for these programs. Many but not all aspects of this library program are subject to interinstitutional cooperation. For those that are subject to a cooperative approach, nearly all types have been explored and are still being pursued. Where staff pressures increase, and as economic circumstances shift and technology develops, buffeted by institutional and national economic conditions, the movement for academic library cooperation advances on different fronts at different times. It seems, however, like an army moving ahead-the cavalry unit or armored tank unit, followed by foot soldiers, supply, communication, and management units, with no one getting far ahead of the others and no unit of the force long ignored.

The economic motive may not always be the eternal catalyst, yet it can be found in every one of the examples eited. ${ }^{31}$ The financial resources used by libraries in their acquisition of materials and provision of service to users create economic environments. Whether they be in publicly or privately supported institutions, they respond to national changes in the economy and to local conditions. Programs have prospered with good fiscal support or have remained static due to inadequate economic studies or an insufficient financial base.

American academic libraries have reached a watershed that is almost as significant as the change from block printing to printing with movable type. This conclusion is based on the presumption that on-line computer-based operational programs constitute a radical and permanent change in cooperative style. When one is freed from most of the constraints of the card catalog, of the U.S. mail, and of locally prepared cataloging data, this adoption of sophisticated on-line computer-based programs may well be by far the most significant change ever achieved in library operations. It is a permanent change in the mode of library operations which should be accomplished during the period 1965 to $1990 .{ }^{32}$

It is not a sudden change, for it has its origins in the early $1950 \mathrm{~s}$; and, indeed, library programs using tabulating machines date from the mid-1930s. Yet if one looks ahead ten years, the college student of 1986 may well find at least 10 percent of all bibliographic citations of the library collections in machinereadable form accessible through a computer terminal; in some instances it may reach 100 percent. It is certain to include all of the more heavily used materials. The student will also be able via the terminal to call upon collections in other libraries, locally and nationally, and have instantaneous loan transactions, only constrained by copyright controls on photocopying and limited by telefacsimile or by the remaining need to send the text by air parcel post. Just as the development of national standards was important in 1876 and 1900 , it again becomes of major importance in the nation's ability to develop a national computer-supported system of libraries.

This shift to on-line computer-based systems nationally linked will face the same type of problems as have been seen in cooperative examples cited above. After reviewing current experience with computerized library and academic resource-sharing networks, Pro- 
fessor Lewis B. Mayhew concluded:

It seems clear that the major problems to be overcome with respect to educational or research use of networks are not technical. Technical problems either have been solved or the directions established to solve them. The real problems are political, organizational and economic. Governmental policy must be refined so as to produce health and balanced growth rather than uneven and unplanned partial growth. Universities, by tradition independent, must find ways of reorganizing their uses of computers so as to optimize effectiveness and institutional autonomy. They need to mature to a point where they will trust external agencies. And as has been indicated earlier, stable, long-range systems of financing must be found. ${ }^{33}$
The economically forced and technologically facilitated cooperation of the 1970s must surely be resulting in just as significant a change in the libraries of the future as the political changes of 1776 created for the new American nation. The thirteen separate states operating independently then formed a federal government with careful orchestration of local authority, regional coordination, selected national standards, and some over-reaching federal programs. At the time the American Library Association was formed in 1876 , the union of interests had recently been reasserted. There would seem to be a close parallel with the state of librarianship in this decade as it applies to cooperative programs among academic libraries.

\section{REFERENCES}

1. An earlier move in this direction was the Librarians' Convention held in New York in 1853. "Proceedings," Norton's Literary Register, 1854, p.49-94.

2. "Co-operative College Cataloguing," American Library Journal 1:435-36 (August 1877).

3. Of historical use are the "Symposium on Printed Catalog Cards," Library Journal 36:543-56 (Nov. 1911), and the volume by Robert B. Downs, Union Catalogs in the United States (Chicago: American Library Assn., 1942).

4. Walter Lichtenstein, "Report to the President of Northwestern University on the Results of a Trip to South America," Northwestern University Bulletin 16:8-9 (Sept. 1915).

5. In this setting the Conference of Graduate Deans and Librarians resulted in The Development of Library Resources and Graduate Work in the Cooperative University Centers of the South; Proceedings .... Held at the Joint University Libraries . . . , ed. Philip G. Davidson and A. F. Kuhlman (Nashville, Tenn.: Joint University Libraries, 1944).

6. A useful work is by Mildred Hawksworth Lowell, College and University Library Consolidations (Eugene: Oregon State System of Higher Education, 1942).

7. M. J. Savary, The Latin American Cooperative Acquisitions Program; An Imaginative Venture (New York: Hafner, 1968).
8. Diana Delanoy and Carlos A. Cuadra, Directory of Academic Library Consortia (Santa Monica, Calif.: System Development Corp., 1971). A second edition by Donald V. Black and Carlos A. Cuadra appeared in spring 1976.

9. Joe W. Kraus, "Prologue to Library Cooperation," Library Trends 24:171 (Oct. 1975). This issue is devoted to "Library Cooperation."

10. Paul J. Fasana, "The Collaborative Library Systems Development Project (CLSDP): A Mechanism for Inter-University Cooperation," in Collaborative Library Systems Development (Cambridge, Mass.: M.I.T. Pr., 1971), p.226-36.

11. Ritvars Bregzis, The Columbia-HarvardYale Medical Libraries Computerized Project-a Review (Toronto: 1966), p.4; see also specific comments on eleven major problems areas on p.17-19. See also Frederick G. Kilgour, "Basic Systems Assumptions of the Columbia-Harvard-Yale Medical Libraries Computerization Project," Information Retrieval with Special Reference to the Biomedical Sciences; Papers Presented at the Second Institute on Information Retrieval, ed. Wesley Siminton and Charlene Mason (Minneapolis: Univ. of Minnesota, 1966), p.145-54.

12. Richard M. Dougherty and Joan M. Maier, Centralized Processing for Academic Libraries: The Final Report, Phase III, Jan. 1-June 30, 1969, of the Colorado Academic 
Libraries Book Processing Center-the First Six Months of Operation (Metuchen, N.J.: Scarecrow, 1971), p.119. See also Allen B. Veaner, "Colorado Academic Libraries Book Processing Center-Consulting Report," June 1972.

13. A useful review is James E. Skipper, "National Planning for Resource Development," Library Trends 14:321-34 (Oct. 1966); see also Robert Vosper, The Farmington Plan Survey: A Summary of the Separate Studies of 1957-1961 ([Occasional Papers, no.77] Urbana: University of Illinois Graduate School of Library Science, 1965).

14. Carlos A. Cuadra and Ruth J. Patrick, "Survey of Academic Library Consortia in the U.S.," College \& Research Libraries 33:271-83 (July 1972).

15. Basil Stuart Stubbs, "An Historical Look at Resource Sharing," Library Trends 23: 662 (April 1975).

16. Joseph Becker, "Information Network Prospects in the United States," Library Trends 17:311-12 (Jan. 1969).

17. John P. McDonald, "Interlibrary Cooperation in the United States," Issues in Library Administration, ed. Warren M. Tsuneishi, Thomas R. Buckman, and Yukihisa Suzuki (New York: Columbia Univ. Pr., 1974), p.131.

18. An extensive list of problems is presented by Merton W. Ertell, Interinstitutional Cooperation in Higher Education; A Study of Experiences with Reference to New York State (Albany: The University of the State of New York, 1957), p.98-100.

19. Charles Coffin Jewett, "A Plan for Stereotyping Catalogues by Separate Titles, and for Forming a General Stereotyped Catalogue of Public Libraries of the United States," Proceedings of the American Association for the Advancement of Science 4:165-76 (Aug. 1850).

20. A useful work is Ruth J. Patrick, Guidelines for the Development of Academic Library Consortia (Santa Monica, Calif.: System Development Corporation, 1971).

21. Robert B. Downs, "American Library Cooperation in Review," College \& Research Libraries 6:407-15 (Sept. 1945, part II).

22. Ernest C. Colwell, "Inter-University Cooperation," Library Quarterly 22:2-3 (Jan. 1952).

23. In this connection, a useful work is Eileen
Thornton, "Cooperation among Colleges," Library Trends 6:309-25 (Jan. 1958).

24. President's Report for 1900-01, p.30-31. See also Library Journal 27:53-54 (1902).

25. Quotations from Stephen A. McCarthy and Raynard C. Swank, "The Report of a Survey with an Outline of Programs and Policies" (Chicago: 1965), as reprinted in Michael M. Reynolds, ed., Reader in $\mathrm{Li}$ brary Cooperation (Washington, D.C.: NCR Microcard Editions, 1972), p.199.

26. Ibid., p. 200.

27. "Articles of Incorporation of the Ohio College Library Center," approved July 6, 1967 , third section.

28. Annual Report $1967 / 68$, p.2-3.

29. From internal draft document, November 1975. Personal communication from James E. Skipper.

30. An exception is the study by $\mathrm{H}$. Joanne Harrar of the NEDL, CRL, and HILC, summarized as "Cooperative Storage Warehouses," College \& Research Libraries 25: 37-43 (Jan. 1964).

31. Note for example a product of the Association of Research Libraries: Problems and Prospects of the Research Library [papers and proceedings of the Monticello Conference], ed. Edwin E. Williams (New Brunswick, N.J.: Scarecrow, 1955).

32. Four seminal works may be cited as omens: (1) Conference on Libraries and Automation, Airlie Foundation, 1963, Libraries and Automation: Proceedings, ed. Barbara Evans Markuson (Washington, D.C.: Library of Congress, 1964); (2) Summer Study on Information Networks, University of Colorado, 1966, Edunet: Report, authors and eds., George W. Brown, James G. Miller, and Thomas A. Keenan (New York: Wiley, 1967); (3) Conference on Interlibrary Communications and Information Networks, 1970, Proceedings, ed. Joseph Becker (Chicago: American Library Assn., 1971); and (4) U.S. National Commission on Libraries and Information Science, Toward a National Program for Library and Information Services: Goals for Action (Washington, D.C.: U.S. Govt. Print. Off., 1975).

33. Lewis B. Mayhew, Computerized Networks among Libraries and Universities: An Administrator's Overview (ED 115220) (Stanford, Calif.: ERIC Clearinghouse on Information Resources, 1975), p.61.

\section{David C. Weber is director \\ of University Libraries, \\ Stanford University, \\ Stanford, California.}

